\title{
Chapter 10 \\ Compounding Impacts of Lifeline \\ Infrastructure Failure During Natural \\ Hazard Events
}

\author{
Emma A. Singh
}

\begin{abstract}
Critical infrastructures, such as transportation systems, communication networks, power and water utilities, have become so integrated into our modern and globalised world that they are commonly taken for granted. That is, until their services are disrupted. The failure of these lifeline services during natural hazard events has the potential to impact populations by exacerbating the hazard itself and/or hindering their ability to respond to or recover from the event. The failure of lifeline infrastructure can also propagate outside the reach of the hazard footprint, causing disruption in regions not directly impacted by the event. Understanding the potential flow-on effects from lifeline failure during natural hazard events is vital for future disaster mitigation, response and recovery. The 2009 South-Eastern Australia heatwave and the 2010 Eyjafjallajökull eruption in Iceland are drawn on to highlight and discuss the vulnerability of lifelines to disruption from natural hazard shocks and the compounding impacts of lifeline failure during natural hazard events.
\end{abstract}

Keywords Critical infrastructure $\cdot$ Lifelines $\cdot$ Natural hazards $\cdot$ Compounding impacts $\cdot$ Indirect disruption $\cdot$ Cascading disasters

\subsection{Introduction}

Lifelines are the critical infrastructure and systems crucial to the distribution and continuous flow of goods and services essential for human livelihoods, the functioning of society and economic prosperity. They include, but are not limited to transportation, telecommunication and utilities such as power and water. Transportation systems are used daily to move people to and from places of work and education, and

This chapter is derived from a section of the author's Ph.D. thesis (Singh 2019); therefore, some segments of the text here are present in both bodies of work.

E. A. Singh $(\varangle)$

Department of Earth and Environmental Sciences, Macquarie University, Sydney, NSW 2109,

Australia

e-mail: emma.a.singh@gmail.com

Bushfire and Natural Hazard Cooperative Research Centre, Melbourne, Australia

(C) The Author(s) 2021

D. Karácsonyi et al. (eds.), The Demography of Disasters,

https://doi.org/10.1007/978-3-030-49920-4_10 
goods between manufacturers, suppliers and customers. Telecommunication systems are used to connect people, conduct business and perform financial transactions. Electricity and gas provide power to homes and industries, and water and sewage systems contribute to the public health of communities (Murray and Grubesic 2007). These lifelines have become so integrated into our modern society that they are commonly taken for granted; that is until something goes wrong. The failure of lifelines can range from being an inconvenience to being debilitating for a population both socially and economically (Davis 1999; Hawk 1999). Being without electricity or water for less than a few hours can generally be tolerated. However, prolonged disruption of such services can lead to major economic losses, deteriorating public health that includes an increase in mortality, and eventually population migration (Rose et al. 1997; Brozovic et al. 2007; Rose and Oladosu 2008, Anderson and Bell 2012; Klinger et al. 2014; Yates 2014). Power failure in Auckland, New Zealand (Leyland 1998); the drinking water quality crisis in Sydney, Australia (Clancy 2000); and gas outages in Victoria, Australia (Dawson and Brooks 1999), that all occurred in 1998, had media pointing out how easy it was for a modern building with lights, heating and plumbing to convert into a third world slum when such services were lost (Hawk 1999). The water crisis had residents boiling drinking water and the gas outage left residents with cold showers (Hawk 1999). Moreover, the power failure in Auckland impacted business operations, with some businesses closing, some temporarily moving out of the $\mathrm{CBD}$ and a few continuing with generators. All suffered a significant drop in income. Those who continued to operate as usual did so at the expense of their staff that had to climb stairs and swelter in the summer heat without air-conditioning or sufficient ventilation (Leyland 1998). The impact of these utility crises could have been more severe if they had lasted for months instead of days to weeks (Hawk 1999).

Lifeline infrastructure often consists of a large number of interconnected components, which often span extensive geographic areas and, in some cases, multiple urban centres, states and international borders (Kinney et al. 2005; Guikema 2009). The concentration of mutually dependent lifeline infrastructure within urban centres results in complex and interconnected systems, creating feedback loops and complex topologies that can trigger and propagate disruptions in a variety of ways (Rinaldi et al. 2001; McEvoy et al. 2012). Consequently, a fault in one lifeline can cascade and directly or indirectly affect other lifelines or services, with impacts potentially felt not just locally but nationally or even globally (McEvoy et al. 2012). Significant power failure, for example, can result in the disruption of telecommunications and transportation systems. The most noted example of this was the Northeast blackout in August 2003 that impacted the Northeastern USA and parts of Canada (USCanada Power System Outage Task Force 2004). This event not only cut power to over 50 million people but also disrupted Internet communications. Banks, manufacturers, business services and education institutions were severely disrupted when they were taken offline for hours to days (Cowie et al. 2003; Murray and Grubesic 2007). The event cost an estimated US\$6 billion (Electricity Consumers Resource Council 2004). The blackout caused major disruptions to the lives of those impacted. Thousands of subway commuters were trapped for hours as trains stopped operating; the closure of major manufacturing plants idled thousands of workers; cars lined for 
blocks waiting for gas; high-rise apartments were left without water services as electric pumps used to deliver water to the upper floors shut off; mass food spoilage occurred due to the loss of refrigeration; and, hospital admissions increased due to an increase in heat exposure, exertion and stress (Electricity Consumers Resource Council 2004; Anderson et al. 2007; Lin et al. 2011). Anderson and Bell (2012) investigated the impacts of the blackout on mortality in New York and found that the event resulted in approximately 90 excess deaths (a rise of $28 \%$ ), with the mortality remaining slightly higher than average throughout August. Although there was a steep rise in accidental deaths, the authors found that the majority of the excess deaths were from disease-related causes rather than non-accidental. This was due to the lack of power (and therefore the cessation of services and equipment that rely on electricity) exacerbating and complicating the management of illness. Those aged between 65 and 74 were particularly susceptible (Anderson and Bell 2012).

Lifelines can be disrupted by various shocks, including structural and technological failure, human error, targeted attack, and of interest in this chapter, natural hazard events (Murray 2013). The often-large footprint of natural hazard events has the potential to cause simultaneous failure of multiple lifeline components, across one or more networks (Erjongmanee et al. 2008). For example: storms can bring down powerlines with strong winds or fallen trees, while simultaneously cutting off transportation routes with floodwater (Chang et al. 2007; King et al. 2016); earthquakes can destroy multiple lifelines, such as pipes and roads, through ground shaking or liquefaction (Menoni 2001; Giovinazzi et al. 2011; O’Rourke et al. 2012; Lanzano et al. 2014); and only millimetres of ash fall from volcanic eruptions can disrupt most lifeline services (Blong 1984; Jenkins et al. 2014; Wilson et al. 2014).

A further complication of natural hazards is the potential for events to be prolonged. They can, for example, have an extended duration of a week or more, or they might consist of a series of events that occur in succession (Blong et al. 2017). Natural hazards can be associated with secondary hazards, which can occur simultaneously or subsequently. Earthquakes, for example, are often associated with liquefaction, landslides, fires, tsunami and aftershocks (EERI 2011; Daniell et al. 2017). Volcanic eruptions are not only associated with a range of phenomena, such as lava flows, lahars, pyroclastic density currents and ash fall (Jenkins et al. 2014; Wilson et al. 2014), but can also be sustained for weeks, months or even years (Siebert et al. 2011; Sword-Daniels et al. 2014). A prolonged natural hazard event can affect a region for an extended period, causing vast and on-going disruptions to lifeline services vital for disaster response and community recovery.

Natural hazard-prone areas, such as coastal zones and volcanic regions, have attracted large populations of people over time due to the presence of food, natural resources and fertile soils (Chester et al. 2001; Small and Naumann 2001; Klein et al. 2003). Today, some of these settlements have grown into large cities, which continue to expand with urbanisation and natural population growth. A significant proportion of these large cities are located in some of the world's lowest socially and economically developed countries (Kummu and Varis 2011) which sit within the cyclone-prone regions near the equator (10-30 degrees latitude). The increasing demand for development has seen populations and infrastructure expanding into 
areas more exposed to natural hazards - such as houses being built on previously avoided flood plains - despite the risk (Huppert and Sparks 2006; Cutter and Finch 2008; Lall and Deichmann 2010). The continual and growing presence of populations and infrastructure within natural hazard-prone areas, combined with climate change impacts, has the potential to intensify the exposure and vulnerability of lifelines to natural hazard shocks (Wu et al. 2002; Van Aalst 2006). Consequently, future lifeline failure, of varying degrees of seriousness, may simply have to be expected (Hawk 1999). It is therefore necessary to better understand how lifelines and their functionality might be impacted when subjected to disruption from disasters, and furthermore, the social and economic costs of lifeline failure for at-risk populations.

This chapter aims to add to this area of knowledge by looking at two case study examples: the impact of extreme heat on electricity and transportation systems during the 2009 South-Eastern Australia heatwave and the closure of the European airspace during the 2010 Eyjafjallajökull eruption in Iceland. This chapter explores the compounding effects of lifeline disruption during natural hazards and, using the learnings following these events, discusses potential changes needed to reduce future vulnerability for at-risk populations.

\subsection{The 2009 South-Eastern Australia Heatwave}

\subsubsection{Hazard}

Heatwaves are extended periods of hot days and nights resulting in little to no relief from high temperatures. According to the Australian Bureau of Meteorology (BoM), an event is considered a heatwave when there are three or more days of unusually high maximum and minimum temperatures (Bureau of Meteorology 2018). Alternatively, Scorcher (2019) defines a heatwave as '... at least three consecutive days where the daily maximum temperature is in the top $10 \%$ of warmest temperatures for that calendar date'.

Heatwaves are known to cause serious health, social and economic problems (McInnes and Ibrahim 2013; Wong 2016). Although not as dramatic as other natural hazards, such as wildfires and major storms, heatwaves can cause great loss of life. The 2003 European heatwave, for example, resulted in extensive loss of life with more than 40,000 heat-related deaths (García-Herrera et al. 2010). In Australia, heatwaves have been the most significant natural hazard in terms of lives lost (except for disease epidemics), causing more than 4,000 deaths over the past 200 years (see also Chap. 8) (McInnes and Ibrahim 2013; Coates et al. 2014).

An individual's ability to respond to a heatwave depends on both the degree of exposure to the heat hazard and their adaptive capacity, which is influenced by social, economic and biophysical factors and their access to resources, technology, information and infrastructure (García-Herrera et al. 2010; Reeves et al. 2010; Coates et al. 2014; Wong 2016). Elderly, very young, ill, urban, marginalised and socially isolated 
residents are often identified as the most vulnerable groups during a heatwave, often lacking the capacity to avoid or reduce exposure to the heat hazard (Reeves et al. 2010). Elderly populations are more likely to experience poor health, social isolation, reduced mobility and lower socio-economic circumstances (McInnes and Ibrahim 2013; Coates et al. 2014). They also tend to have a reduced thermoregulatory and physiologic heat-adaptation capability and an altered sense of thirst (McInnes and Ibrahim 2013; Coates et al. 2014). Urban populations experience higher ambient temperatures than neighbouring rural areas due to the urban heat island effect (Wong 2016; Petkova et al. 2014). The homeless are often neglected in impact assessments but are at considerable risk from heat exposure during heatwave events. This population has compromised health; limited access to resources including food, water and shelter; and, this increased risk of exposure is often coupled with the use of drugs and alcohol (Reeves et al. 2010).

Heatwaves can put a strain on medical facilities and support services, not just with an increase in morbidity but also by impacting the lifelines that support services heavily rely on such as electricity systems and transportation infrastructure (Reeves et al. 2010). Heatwaves can cause an increase in demand on electricity grids as residents turn to air-conditioning and electric fans to keep cool (Miller et al. 2008). On top of this, high temperatures can impact the electricity infrastructure directly. Most problems occur when underground transmission lines overheat and short out or when overheated above ground power lines, which have stretched and sagged, come into contact with trees and short to the ground (Palecki et al. 2001). To keep systems from overheating and to avoid complete electricity outage, the total amount of energy produced must be reduced and distributed to end-users (McEvoy et al. 2012). To mitigate overheating and potential fires produced from electrical system faults, rolling blackouts can be enforced (Broome and Smith 2012).

Extreme temperatures experienced during heatwave events can also directly impact transportation infrastructure by buckling rail lines and melting roads (Palecki et al. 2001; Zuo et al. 2015). Indirectly, transportation systems such as public transport and traffic signals, which rely on power to operate, can be impacted by the loss of electricity (Rinaldi et al. 2001). Extreme temperatures can also affect the health of public transport employees and passengers (Reeves et al. 2010; McEvoy et al. 2012).

\subsubsection{Event Overview}

In 2009, South-Eastern Australia experienced its most extreme heatwave on record. The states of Victoria and South Australia were exposed to severe, extensive and prolonged heat across two weeks in January and February. These conditions were caused by the stalling of a hot air mass over South-Eastern Australia due to slowchanging synoptic conditions, with sea and bay breezes providing only little relief in coastal areas (Reeves et al. 2010; McEvoy et al. 2012). During this period, new daily maximum temperatures were observed for Adelaide $\left(45.7^{\circ} \mathrm{C}\right)$ and Melbourne $\left(46.4^{\circ} \mathrm{C}\right)($ Reeves et al. 2010), the state capital cities for South Australia and Victoria, 
respectively. Adelaide experienced eight consecutive days over $40^{\circ} \mathrm{C}$ and Melbourne had three days over $43{ }^{\circ} \mathrm{C}, 12-15^{\circ} \mathrm{C}$ above the seasonal average (Reeves et al. 2010; McEvoy et al. 2012). The Victorian town of Hopetoun experienced a record high of $48.88^{\circ} \mathrm{C}$ (McInnes and Ibrahim 2013).

The extreme heat experienced during the 2009 heatwave resulted in a dramatic increase in mortality and morbidity. The persistent high temperatures resulted in increased cases of heat-related illness and exacerbated chronic disease. There was an increase in emergency ambulance dispatches and presentations of heat-related conditions at emergency departments (Reeves et al. 2010; Lindstrom et al. 2013). The extreme heat resulted in an estimated 374 excess deaths in Victoria and between 50 and 150 excess deaths in South Australia (Department of Human Services 2009; Reeves et al. 2010; McInnes and Ibrahim 2013). Most of the deaths that occurred in Victoria during the 2009 South-Eastern Australia heatwave were those aged 75 years or over (Table 10.1) (Department of Human Services 2009; Reeves et al. 2010; Bi et al. 2011; McInnes and Ibrahim 2013). In Adelaide, South Australia, Zhang et al. (2013) found that the populations most at risk during the heatwave were those who lived alone, had a lower socio-economic status, had renal problems or were at risk of falls and needed help from community services. It was also noted that occupational heat exposure could have been a cause of an increase in hospitalisations of workingage men (35-64 years) during the 2009 event (Reeves et al. 2010; Bi et al. 2011). However, this needs further investigation.

Table 10.1 Total mortality between 26 January and 1 February 2009: Expected deaths (derived from mean deaths in 2004-2008) versus 2009 reported deaths (based on data extracted from Department of Human Services (2009))

\begin{tabular}{r|r|r|r|r|r}
\hline \multicolumn{1}{l|}{ Age } & Expected deaths & 2009 deaths & Excess deaths & \% Total excess & \% Increase \\
\hline$\geq 75$ & 388 & 636 & 248 & 66 & 64 \\
\hline $65-74$ & 99 & 145 & 46 & 12 & 46 \\
\hline $5-64$ & 116 & 180 & 64 & 17 & 55 \\
\hline $0-4$ & 4 & 7 & 3 & 1 & - \\
\hline Unknown* & - & $\sim 12$ & $\sim 12$ & $\sim 4$ & - \\
\hline Total & $606^{* *}$ & 980 & $374 * * *$ & 100 & 62 \\
\hline
\end{tabular}

*A small number of deaths were reported with unknown age

** Total noted in Department of Human Services (2009), sum of expected deaths here is 607. Difference may be due to rounding

*** Total noted in Department of Human Services (2009), sum of expected deaths here is 373. Difference may be due to rounding 


\subsubsection{Lifeline Disruption and Compounding Impacts}

On 29 and 30 January 2009, Melbourne experienced rolling blackouts due to a combination of failures that occurred throughout the system. Supply was impacted when the Basslink electricity supply connection between Tasmania and Victoria was shut down due to heat-related issues, and Victorian generators were unable to supply additional power. Transformer faults resulted in outages of major transmission lines, and supply loads were restricted in the Western metropolitan area. Additional faults occurred in up to 50 local voltage transformers. Load shedding was finally required to protect the security of the electricity network, further restricting supply (Reeves et al. 2010; McEvoy et al. 2012). Cumulative system faults, ageing infrastructure and a rapid increase in demand (breaking Victoria's load record by $7 \%$ ), primarily from the use of air-conditioning, all contributed to the system's vulnerability to the heatwave (Reeves et al. 2010; McEvoy et al. 2012). Rolling blackouts resulted in over 500,000 residents being without power on the night of 30 January. The outages occurred for 1-2 hours, but the ripple effects lasted up to two days (McEvoy et al. 2012).

The periodic loss of electricity limited access to air-conditioning, electric fans and refrigeration, key aids that people rely on to cope with prolonged high temperatures. This was especially detrimental to those most vulnerable to heatwaves, such as the elderly, ill and isolated (Reeves et al. 2010). This event also showed how vitally important night-time relief from extreme heat is. During the 2009 heatwave, many deaths occurred overnight where residents were found in stuffy rooms with air-conditioning turned off (Reeves et al. 2010). In these cases, it was not just the blackout that hindered the use of such services, but the cost of electricity also, with many residents unable to afford to continually run air-conditioning units overnight (Reeves et al. 2010).

Transportation systems suffered minor to moderate disruptions during the heatwave, with rail being the most affected by the high temperatures. During the initial heatwave peak (27-30 January), more than a third of the train services were cancelled in Melbourne and 7\% in Adelaide (Reeves et al. 2010; McEvoy et al. 2012). There were nearly 30 reported instances of track buckling in Melbourne, which slowed down or disrupted services and increased maintenance and repair expenses for the rail transport industry (McEvoy et al. 2012). Also, half of the train fleet were older stock with air-conditioning units not designed to operate above $34.5^{\circ} \mathrm{C}$. Air-conditioning failure was the leading cause for service cancellations due to industrial action taken by train drivers (Reeves et al. 2010; McEvoy et al. 2012). This is an important factor often forgotten when considering critical infrastructure vulnerability. Although there may not be any direct impacts to infrastructure components, workers themselves may not be able to continue to operate the systems under extreme heat conditions. The operation of lifelines can also rely on the operation of other lifeline infrastructures. Electricity outages, for example, resulted in the indirect disruption of transportation systems. Rolling blackouts on 30 January impaired traffic signals at 124 intersections in Melbourne and resulted in the cancellation of city loop train services, stranding a 
large number of inner-city commuters (Reeves et al. 2010). Overall, power outages and transport disruption resulting in an estimated financial loss of AU\$800 million (Reeves et al. 2010).

Although transport was not vital in mitigating heat exposure, forcing commuters to use alternatives, such as biking or walking, could lead to increased exertion and exposure to extreme heat conditions. The loss of train services also impacted public transport users by disrupting their access to work, home or loved ones. With public transport often being an affordable form of transport for students, the elderly and poor, the loss of operation largely impacted the mobility of these demographic groups (Rodrigue et al. 2017).

\subsubsection{Learnings}

The 2009 heatwave was characterised by a substantial increase in health service demand and disruptions to electricity supplies and public transport systems. Governments, councils, utility providers, hospitals, emergency response organisations and the community were largely underprepared for an event of this magnitude, with the extreme conditions not anticipated in seasonal forecasts (Reeves et al. 2010). The number of excess deaths (approximately 374) demonstrates demographic impacts from severe heatwaves are most acute for older residents (at $66 \%$ of excess deaths of those 75 years or older) (see Table 10.1).

Reeves et al. (2010) concluded in their report on the 2009 event that extreme heat should be given the same prominence as high-impact natural hazards such as wildfires or flooding with regards to impacts on lifeline infrastructure. The report highlighted how vulnerable lifelines, specifically electricity and transportation systems can be to heat stress and how significant the impacts of lifeline failure, both direct and indirect, can be for people and the urban system. Overall it was noted, 'people mostly manage when they have power, when they have transport' (Reeves et al. 2010 p. 99). The loss of these services had adverse affects on people's ability to cope and compounded the experience of the heatwave event. Broome and Smith (2012) calculated that being without power, and therefore air-conditioning, would increase the risk of those susceptible of dying from heat-related illness by 50\%, especially among the elderly and those in remote rural communities. These authors estimated that if electricity was cut for an entire day in Victoria during the 2009 heatwave, 28 additional deaths could have occurred. Therefore, the urban system as a whole, including lifelines, needs to be considered in future risk assessments and mitigation measures.

Following the 2009 heatwave event, both South Australia and Victoria moved from a reactive and response-driven approach to mitigation and risk reduction. Health and emergency services developed strategies to identify and manage vulnerable groups (Reeves et al. 2010). Vulnerabilities and lack of redundancy in lifelines, such as transport and power, were highlighted. Attitudinal, socio-economic, behavioural and financial barriers to improve resilience in future heatwave events were also identified. Specifically, the increase in population vulnerability to heat-related mortality due to 
an ageing population and an increase in obesity in adults were highlighted as areas in need of attention (Petkova et al. 2014). It was also identified that there was an increase in the expectation and dependence on emergency services for warnings and timely advice (Reeves et al. 2010). It must be noted, however, that the unfortunate occurrence of the Black Saturday bushfires during the second phase of the heatwave overshadowed the impacts of the heatwave itself, hindering the publicity of the huge health impacts of the 2009 heatwave, lifeline vulnerabilities to extreme heat and post-event reflection.

In January 2014, South-Eastern Australia was again hit by a heatwave. Although maximum temperatures were not as high as those experienced during January 2009, mean temperatures were higher and the heatwave peak lasted for longer (four days in 2014 compared to three days in 2009) (Department of Health 2014). The 2014 heatwave resulted in an estimated 167 excess deaths in Victoria, compared to the 374 excess deaths in 2009. The decrease in estimated excess mortality was contributed to the implementation of Victoria's Heatwave Plan (Department of Health 2014). Since 2014, the Victorian State Government also focused on educating vulnerable populations on how to be prepared for electricity failure in their 'How to cope and stay safe in extreme heat' brochures (Victoria State Government 2015). Additional research is needed to determine if this information positively influences people's preparedness for, and actions during, heatwave events in the future. It would also be interesting to see if this information reached those most vulnerable.

The transportation sector also took steps to adapt to extreme heat events by: upgrading rail infrastructure to prevent track buckling; creating better heat policies for drivers and providing easier access to cold water and ice; and creating better contingency plans including providing stand-by replacement services (Chhetri et al. 2012). The 2014 heatwave resulted in minor disruption to Melbourne's public transport as trains operated at reduced speeds (Mullett and McEvoy 2014). The electricity sector also fared better in 2014 with the system avoiding load shedding during the highest temperature period. Only small local distribution outages were experienced due to distribution equipment failure; however, periods of low reserves were of concern. AEMO (2014) highlighted that any fault with an interconnector or major generator could have changed the outcome and resulted in load shedding. The system's ability to cope in 2014 was in part attributed to the contribution of embedded solar photovoltaic (PV) generation, namely in South Australia, which helped to support the peak usage period (AEMO 2014).

There is still much to be done to increase resilience and adaptation capacity to heatwaves within Australia. Although many stakeholders took steps to assure future risks were being adequately managed, they appeared to have done so in isolation (McEvoy et al. 2012). Due to the integrated nature of the urban system, there is a need for all stakeholders to take on a 'whole system' approach. McEvoy et al. (2012) concluded that sectoral segmentation and the lack of holistic urban infrastructure management are major barriers to improving urban resilience to future heatwave events.

Heat-sensitive infrastructures such as the electricity network and rail transport will continue to be vulnerable to extreme heat events in the future, compounding the 
impacts of events. A warming climate may make heatwaves more likely (Meehl and Tebaldi 2004; Revi et al. 2014), putting more pressure on expanding urban areas (McInnes and Ibrahim 2013). Expanding urbanisation and high-density housing will also exacerbate the situation through urban heat island effects (Coates et al. 2014; Petkova et al. 2014; Wong 2016). Furthermore, populations are increasingly living and working in climate-controlled environments, relying on air-conditioning to reduce heat stress and therefore isolating people from a changing climate and limiting their ability to acclimatise (Coates et al. 2014; Reeves et al. 2010). This further increases the dependence on air-conditioning, whose operation cannot be guaranteed during a heatwave. Air-conditioning is also counter-productive in reducing the risk of heat stress. Farbotko and Waitt (2011) note that the use of air-conditioning to decrease resident exposure to extreme heat results in a spike in energy demand during a heatwave, which contributes to system-wide blackouts, hiking energy prices as a result and exacerbating existing social-economic inequalities. On top of this, the waste heat released from air-conditioners also contributes to higher outside temperatures, worsening the urban heat island affect (Salamanca et al. 2014).

\subsection{The 2010 Eyjafjallajökull Volcanic Eruption, Iceland}

\subsubsection{Hazard}

Volcanic ash is the material produced by explosive volcanic eruptions and is made up of tiny fragments of rock and glass (Wilson et al. 2012). Volcanic ash can spread far and wide; it is hard, highly abrasive, corrosive and conductive; and only millimetres are needed to disrupt most essential lifeline services (Blong 1984; Barsotti et al. 2010; Wilson et al. 2011, 2012; Magill et al. 2013; Jenkins et al. 2014). Ash easily infiltrates openings, clogs air-filtration systems and abrades surfaces (Jenkins et al. 2014). Air transportation, in particular, can be impacted by volcanic ash both on the ground and in the air. Airline operations can be affected by ash falling on airport runways, and if volcanic ash is erupted high enough into the atmosphere, it can become a risk to flying aircraft (Casadevall 1994; Jenkins et al. 2015; Webley 2015).

The risk volcanic ash poses for modern aviation was brought to attention in 1982 when a British Airways flight flew through high concentrations of volcanic ash produced by an eruption at Mount Galunggung in West Java. The Boeing 747 lost power to all four engines and lost over 12,000 feet of altitude before restoring power and making an emergency landing in Jakarta (Lund and Benediktsson 2011; Ellertsdottir 2014; Gislason et al. 2011). The 1989 Redoubt eruption in Alaska, and 1991 Mount Pinatubo eruption in the Philippines, also caused engine failure and extensive damage to aircraft engines and windshields that came in contact with ash clouds (Przedpelski and Casadevall 1994; Casadevall et al. 1996; O'Regan 2011; Webley 2015). With the conclusion that volcanic ash can cause jet-engine failure, great financial loss and potentially loss of life, a 'no-threshold' guideline was, at the time of the 2010 Eyjafjallajökull eruption, universally adopted and no-fly zones 
were implemented whenever volcanic ash was detectable in airspace (O'Regan 2011; Ellertsdottir 2014).

\subsubsection{Event Overview}

On 20 March 2010, fire-fountain activity started along a fissure at Fimmvörðuhálsi, an ice-free area between Eyjafjallajökull and Mýrdalsjökull volcanic vents in Iceland, and ended on 13 April, leading many to believe that it was the end of the eruption (Donovan and Oppenheimer 2011; Porkelsson et al. 2012). However, on 14 April, the eruption resumed, this time at the summit of Eyjafjallajökull. The interaction of ice and melt water with a more viscous batch of magma resulted in a more explosive eruption than the first phase (Donovan and Oppenheimer 2011; Gislason et al. 2011; Porkelsson et al. 2012), sending ash up to $10 \mathrm{~km}$ in the atmosphere (Carlsen et al. 2012; Porkelsson et al. 2012; Stevenson et al. 2012).

Ash fell to the South of the volcano impacting rural communities, causing impacts to agriculture and local tourism (Adey et al. 2011; Donovan and Oppenheimer 2011; Bird and Gísladóttir 2012; Bird et al. 2018). The eruption was accompanied by a number of glacial outburst floods, which impacted roads and farmland and resulted in the evacuation of $\sim 800$ residents (Porkelsson et al. 2012). The majority of Iceland to the North of the volcano was relatively unaffected by the ash. Reykjavik, in particular, saw limited impacts despite being less than $150 \mathrm{~km}$ away from the volcano, with the airport being briefly closed on the 21 April (Lund and Benediktsson 2011; Porkelsson et al. 2012). The most significant impact was caused by ash that remained in the atmosphere. This airborne ash was rapidly blown to the South and East towards mainland Europe and caused the largest shutdown of European airspace since World War II (Budd et al. 2011; Ellertsdottir 2014).

As the volcanic ash cloud from Iceland made its way across Europe, the European Aviation Authorities progressively closed sectors of airspace due to fears for public safety (Ellertsdottir 2014). The airspace over Scotland and Norway was first to close on the evening of 14 April. Irish, Dutch, Belgian and Swedish airspace also saw restrictions as the ash spread further South and East. By 18 April, airspace over Ireland, Ukraine, and Canary Islands was also closed (Budd et al. 2011). Flight restrictions were lifted on 21 April with close to normal air traffic resuming the next day (Ellertsdottir 2014). Over the seven-day period, more than 100,000 flights in, out and around Europe were cancelled (Budd et al. 2011, IATA 2010, Oxford and Economics 2010). The worst affected places were the United Kingdom, Ireland and Finland, who experienced a 90\% decrease in air traffic (Ellertsdottir 2014). Maximum closure of airspace occurred on 18 April which grounded nearly 30 per cent of the world's scheduled flight capacity, costing the airline industry US1.7 billion in lost revenue (IATA 2010). This loss could not typically be claimed under the airlines' business interruption insurance since there was no 'material damage' (O'Regan 2011). It was reported that aviation companies risked being sent into bankruptcy if the closure had lasted much longer (Ellertsdottir 2014). 


\subsubsection{Flow-On Effects from Lifeline Disruption}

The European airspace is one of the busiest in the world, used by 150 airlines making 9.5 million flights every year across 150,000 air routes (O'Regan 2011). The airspace and aircraft that occupy it form part of a large interconnected network that provides private, military and economic mobility. The complex network of flight paths, airways and control zones, navigated by flight crew, air traffic control, collision avoidance software and controlled by strict international regulations, is largely unseen by passengers (Budd et al. 2011). It is a system often taken for granted until flights are delayed, diverted or cancelled.

The impact of the closure of the European airspace in 2010 was far-reaching and uncovered a vast dependence on global air travel for the mobility of people and product. Air transport is relied upon by manufacturers to join spatially disaggregated operations and enables time-sensitive and perishable freight to be carried over long distances in a short time (Bowen and Leinbach 2006; Pedersen 2001; Button and Yuan 2013; Mukkala and Tervo 2013; Rodrigue et al. 2017).

Shortages of imported flowers, fruits and electronic hardware were reported in the immediate days after airspace closure. Pharmaceutical, automotive, transport and delivery companies were also impacted. The hardest hit were those supply chains that rely on airfreight for just-in-time deliveries and exporters of perishable goods. Where some products could be delivered later, perishable goods could not (Oxford Economics 2010). Flower and fruit growers in Africa were especially hard hit, with fresh products due to be air-freighted to Europe being left to rot (Oxford Economics 2010; Budd et al. 2011; Ellertsdottir 2014). The World Bank estimated that the airspace shutdown cost African countries US\$65 million in exports (Oxford and Economics 2010). Kenya's flower and vegetable industry, which contributes over a fifth of the country's GDP, employs tens of thousands of workers. During the closure of the European airspace planes that were due to carry the produce to Europe remained grounded at Nairobi's international airport and the industry lost an estimated \$1.3 million per day (Wadhams 2010). The unmoveable produce had to be thrown out or composted, and thousands of workers were temporarily laid off. Although working conditions on Kenyan farms has improved since the formation of the Kenya Flower Council in 1999, the majority of workers are paid below a living wage and unable to amass any savings (Nowakowska 2015; Leipold and Morgante 2013). Therefore, being without paid work for any extended period of time would vitally disadvantage people who depend on the farms for their livelihood.

The halt of air travel around Europe also led to shortages of air-freighted components necessary for electrical and car manufacturing. For example, car production at Nissan and BMW plants in the USA, Japan and Germany was temporarily suspended due to delays in the delivery of pressure sensors (Oxford and Economics 2010).

The estimated 10 million travellers that were stranded by this event faced significant delays and additional costs (Budd et al. 2011; Oxford and Economics 2010). Those unable to afford alternative transportation or accommodation were stuck at airports (Ellertsdottir 2014). Fortunately, many passengers were compensated for 
cancelled flights by the airlines, as required by the European Regulation 241/2004 (Ellertsdottir 2014). The low-cost airlines, which were hard hit by the event economically, contested passenger compensation requested by the European Commission arguing that the situation was outside of their control. However, the European Commission continued to hold the airlines responsible for their passengers (Ellertsdottir 2014).

The week-long cessation of air travel over the United Kingdom and Europe reduced global mobility, impeded economic activities and hindered social connections. Reducing transportation to land and sea, which is generally confined by geographic barriers, dramatically increases travel time, disrupts supply chains and results in the isolation of some populations and economies. Any extended halt to a large portion of the world's air transport capabilities would ultimately impact on development, globally. It was fortunate that the 2010 eruption was relatively short-lived, as past eruptions at Eyjafjallajökull—and other volcanoes around the world-have lasted for months to years (Gertisser 2010).

\subsubsection{Learnings}

With around 60 volcanic eruptions occurring world-wide every year, volcanic ash, or the potential for it, causes airspace restrictions on an almost daily basis (Donovan and Oppenheimer 2011). Iceland's volcanoes, in particular, produce around 20 eruptions per century, many involving significant explosive activity (Langmann et al. 2012). Tephra from numerous eruptions from Icelandic volcanoes over the past 7,000 years were documented to have reached Europe (Swindles et al. 2011; Stevenson et al. 2012). The 2010 eruption at Eyjafjallajökull itself was not an extraordinary event. However, the disruption it caused, to an industry that should have been prepared for its occurrence, was.

Although the risk of volcanic ash was recognised by scientists, operational meteorological institutes and aviation authorities, it was considered a relatively low risk and therefore had not penetrated into policy (Adey et al. 2011; Donovan and Oppenheimer 2011). Because of this, the relatively small eruption of 2010 required a hasty and extreme response, which resulted in the reactive formation of advisory committees and meetings throughout Europe (Bonadonna and Folch 2011a, b; Donovan and Oppenheimer 2011; Bonadonna et al. 2012).

The heavy reliance on the airline industry for world trade and transportation resulted in the 'no-threshold' guideline, which was in place at the time of the 2010 eruption, being questioned. Decision-makers were caught between public safety concerns and the demanding need for global mobility (Lund and Benediktsson 2011). The complete closure of European airspace was seen as an overreaction, and a review of the normal procedures was demanded. A study by Gislason et al. (2011) on the physical and chemical properties of the Eyjafjallajökull ash showed that very sharp, hard and fine-grained particles could have put aircraft at risk from abrasion and melting in jet engines. However, at the time, what constituted a safe concentration 
of volcanic ash was highly contested among international safety regulators, airlines, aircraft engineers and manufactures (Budd et al. 2011; Ellertsdottir 2014). As a result, major airlines, including Lufthansa, KLM and British Airways, performed a series of test flights and determined that 2,000 microg of ash per cubic metre was an accepted threshold through which aircraft could fly (Budd et al. 2011; O'Regan 2011).

The response to the 2010 eruption and airspace closure was hindered by the lack of data detailing ash tolerance of aircraft and engines and the inability of international safety regulators, airlines, aircraft engineers and manufactures to agree on a 'safe' concentration of atmospheric ash (Budd et al. 2011). Budd et al. (2011) also highlighted that national policies were not aligned with other countries, such as the USA. Had the creation of advisory groups occurred before the eruption, rather than a reactive scramble, preparations could have been made both politically and financially, and safe ash thresholds predetermined (Donovan and Oppenheimer 2011).

This event highlighted the dependency on global mobility and the need to recognise that natural hazards and their impacts are not always confined to geographical or political boarders. Globalisation turned an ordinary geological event into near worldwide chaos. Economies around the world have been made more vulnerable to disruptions to the normal flow of goods by increased globalisation in trade, outsourcing and the advent of leaner global supply chains, focused on cutting costs (Besedeš and Murshid 2017). In the aftermath of the 2010 Eyjafjallajökull eruption, there was a call for increased supply chain flexibility through adaptive logistic capacities and sourcing products from various locations. In their paper on the trade-effects of airspace closures in the aftermath of Eyjafjallajökull Besedeš and Murshid (2017) found that some supply chains were able to combat some of the disruptions. The authors found that the US market, in particular, was able to form trading relationships with countries outside of Europe to supplement some of the lost supplies.

The African flower and vegetable growers, on the other hand, did not have fallback options. The flower market in Kenya depends almost wholly on Europe for its exports. With a low domestic demand, the industry (Kenya's top exchange earner) is at the peril of fluctuating foreign demand and the availability of airfreight into Europe (Leipold and Morgante 2013; Kargbo et al. 2010). At the time, Kenyan horticulture was still recovering from previous impacts from domestic post-election violence in 2008/2009 (Justus 2015). These disruptive events resulted in the call for Kenya's flower and vegetable industry to reduce over-dependency on foreign global markets and diversify into local and regional alternative market outlets to provide a shortterm market shock cushion (Justus 2015; Leipold and Morgante 2013). Once some airports reopened tons of produce was flown to Spain and put on trucks to Northern Europe (Gettlemen 2010).

The 2010 Eyjafjallajökull eruption was an expensive lesson to learn but, undoubtedly, it better prepared the airline industry and global businesses for future volcanic eruptions. This was highlighted in 2011 when another Icelandic volcano, Grímsvötn, began to erupt. At its peak, the eruption column reached a height of $20 \mathrm{~km}$, compared to approximately $10 \mathrm{~km}$ of Eyjafjallajökull's and produced nearly twice as much volcanic ash (Stevenson 2012). Although the 2011 eruption of Grímsvötn was nearly 100 times larger in magnitude than that of Eyjafjallajökull in 2010, it did not have 
the same impact. The situation was different, with different eruption parameters and weather conditions, and prevailing winds prevented large amounts of ash from entering international airspace. Ash that entered the airspace was better dealt with. The new rules around safe ash concentrations meant the disruption in Europe was relatively minor, with just 900 out of 90,000 scheduled flights cancelled during the first three days of the eruption compared to 42,600 flights cancelled in the first three days in 2010 (European Commission 2011; Parker 2015).

\subsection{Discussion}

The failure of lifeline networks during natural hazard events has the potential to impact populations by exacerbating the hazard itself and/or hindering the ability to respond to or recover from the event. The primary demographic impact seen in the case of lifeline failure in 2009 in South-Eastern Australia was excess mortality, particularly in older age groups. Lifeline failure can also propagate outside the reach of the hazard footprint, causing disruption in regions not directly impacted by the event. In the case of the 2010 Eyjafjallajökull eruption, one of the industries hardest hit was the flower and fruit growers in Africa, $~ 8,500 \mathrm{kms}$ away.

The outcomes of both these case study events were influenced by unpreparedness. For South-Eastern Australia it was the magnitude of the event itself. South-Eastern Australia has suffered from heatwave events previously (e.g. 1908 and 1939) but the heatwave of 2009 was extraordinarily extensive, long-lasting and severe compared to previous events (Chhetri et al. 2012). Meanwhile, potential impacts from Icelandic volcanos for the United Kingdom/Europe were a scenario deemed unlikely and hence previously ignored. Both events became the much needed wakeup call to spark major reviews of management plans and policies. Implementation of various recommendations has since proven to be beneficial, improving the management of subsequent events.

The improvements made in each case study are commendable. However, particularly in the case of South-Eastern Australia, the approach to hazard mitigation was disjointed with minimal sector cross-over. In their report on Australia's response and adaptation to major weather events, Chhetri et al. (2012) found that individual post-event actions usually only result in small improvements in overall resilience. To improve urban-wide resilience to natural hazard events, there is a need to improve communication, information sharing, collaboration and coordination between all sectors. The fragmented nature of critical infrastructure sectors, like transportation and electricity, and the spanning of lifeline infrastructure across local or state government borders can make the development of coordinated policies and planning frameworks a challenge, hindering a structured response to natural hazard shocks.

The world has never relied on lifelines as much as it does now, and our reliance on lifeline services and technology will only continue to grow alongside increasing urbanisation and ageing populations. The increasing concentration of populations and built environments in hazard-prone regions combined with the impacts of climate 
change are likely to increase the exposure of critical infrastructure and essential services to natural hazard shocks. Future natural hazard events can almost always be expected to result in lifeline disruption or failure. Not only is it important to make lifeline infrastructure more resilient to disruption from future shocks, there is also a need to increase resilience by preparing communities to better cope with service outages.

Furthermore, with an increasingly connected world there is potential for the cost of indirect disruption — both economic and social — to match, if not surpass, the cost of direct damage from hazard events and the case studies in this chapter show how costly it is to be caught unprepared. To be resilient to disruption in this globalised world, we need to look 'beyond our backyards' and acknowledge that lifelines can often span large geographic areas, with the ripple effects of disruption felt beyond regional and national borders. The vulnerability of lifelines to disruption from disasters is also dependent on the quality and management of infrastructure. The impacts of lifeline failure on a population depend on the time it takes for the lifeline to return to operation and who is responsible for the cost of repairs and resulting disruption.

Societal factors such as increasing disparities in wealth and health can contribute to greater vulnerability of particular sections of the population (Cutter et al. 2000). It has been demonstrated time and again how demographics—age, ethnicity, income, gender and housing - can influence (amplify or reduce) overall vulnerability to natural hazards (Donner and Rodríguez 2008; Wisner et al. 2004; Cutter et al. 2003, 2000). This chapter has shown that the ability to cope with lifeline failure is also dependent on these factors. Therefore, in preparation for the true impacts of future natural hazard events on modern society, we need to better understand the interconnectedness and behaviour of lifeline networks and to identify vulnerable populations that rely on their operation. Future disaster mitigation plans not only need to incorporate lifeline infrastructure systems but also take into account the ability of the population to adapt or cope with lifeline disruption. To do this, more work needs to be done in measuring the social impacts of lifeline failure. In their review on power outages during extreme natural events, Klinger et al. (2014) found that power outages resulted in health impacts by inhibiting people accessing healthcare but noted there were few attempts to quantify health impacts in terms of morbidity, mortality or quality of life in the literature. The authors note that this area of research can be difficult but stress that more work needs to be done so we can learn from past events and improve resilience for the future. It is not only the failings that we should look at either but also successes, where communities manage to avoid lifeline failure during extreme events or were able to come up with solutions for outages. More work is needed in collating effective strategies so that these experiences and knowledge can be shared and utilised (Klinger et al. 2014).

Acknowledgments The author thanks Dr. Christina Magill and Dr. Deanne Bird for editing this chapter. The author also acknowledges financial support from the Bush-fire and Natural Hazards Cooperative Research Centre, Macquarie University Research Excellence Scholarship and a scholarship top top-up from Risk Frontiers. 


\section{References}

Adey, P., B. Anderson \& L. L. Guerrero (2011) An ash cloud, airspace and environmental threat. Transactions of the Institute of British Geographers, 36, 338-343.

AEMO. (2014) Heatwave 13-17 January 2014. Australian Energy Market Operator.

Anderson, C. W., J. R. Santos \& Y. Y. Haimes (2007) A risk-based input-output methodology for measuring the effects of the August 2003 Northeast Blackout. Economic Systems Research, 19:2, 183-204.

Anderson, G. B. \& M. L. Bell (2012) Lights out: Impact of the August 2003 power outage on mortality in New York, NY. Epidemiology (Cambridge, Mass.), 23, 189-193.

Barsotti, S., D. Andronico, A. Neri, P. Del Carlo, P. Baxter, W. Aspinall \& T. Hincks (2010) Quantitative assessment of volcanic ash hazards for health and infrastructure at Mt. Etna (Italy) by numerical simulation. Journal of Volcanology and Geothermal Research, 192, 85-96.

Besedeš, T. \& A. P. Murshid (2017) Experimenting with Ash: The Trade-Effects of Airspace Closures in the Aftermath of Eyjafjallajökull. Working paper. Georgia Institute of Technology. Available at: https://besedes.econ.gatech.edu/wp-content/uploads/sites/322/2017/08/besedes-volcano. pdf Accessed 22/05/2019.

Bi, P., S. Williams, M. Loughnan, G. Lloyd, A. Hansen, T. Kjellstrom, K. Dear \& A. Saniotis (2011) The effects of extreme heat on human mortality and morbidity in Australia: implications for public health. Asia Pacific Journal of Public Health, 23, 27S-36S.

Bird, D. K. \& G. Gísladóttir (2012) Residents'attitudes and behaviour before and after the 2010 Eyjafjallajökull eruptions-a case study from southern Iceland. Bulletin of volcanology, 74, 1263 1279.

Bird D.K., Jóhannesdóttir G., Reynisson V., Karlsdóttir S., Gudmundsson M.T., Gísladóttir G. (2018) Crisis Coordination and Communication During the 2010 Eyjafjallajökull Eruption. In: Fearnley C.J., Bird D.K., Haynes K., McGuire W.J., Jolly G. (eds) Observing the Volcano World. Advances in Volcanology (An Official Book Series of the International Association of Volcanology and Chemistry of the Earth's Interior - IAVCEI, Barcelona, Spain). Springer.

Blong, R., C. Tillyard \& G. Attard. (2017) Insurance and a Volcanic Crisis-A Tale of One (Big) Eruption, Two Insurers, and Innumerable Insureds. In Advances in Volcanology. Berlin, Heidelberg: Springer.

Blong, R. J. (1984) Volcanic hazards: a source book on the effects of eruptions. Sydney: Academic Press.

Bureau of Meteorology (2018). About the Heatwave Service. https://www.bom.gov.au/australia/ heatwave/about.shtml Accessed 5/6/2018.

Bonadonna, C. \& A. Folch. (2011a) Ash Dispersal Forecast and Civil Aviation Workshop Consensual Document.

Bonadonna, C. \& A. Folch. (2011b) Ash Dispersal Forecast and Civil Aviation Workshop - Model Benchmark Document.

Bonadonna, C., A. Folch, S. Loughlin \& H. Puempel (2012) Future developments in modelling and monitoring of volcanic ash clouds: outcomes from the first IAVCEI-WMO workshop on Ash Dispersal Forecast and Civil Aviation. Bulletin of Volcanology, 74, 1-10.

Bowen, J. T. \& T. R. Leinbach (2006) Competitive advantage in global production networks: air freight services and the electronics industry in Southeast Asia. Economic Geography, 82, 147-166.

Broome, R. A. \& W. T. Smith (2012) The definite health risks from cutting power outweigh possible bushfire prevention benefits. Medical Journal of Australia, 197, 440.

Brozović, N., D. L. Sunding \& D. Zilberman (2007) Estimating business and residential water supply interruption losses from catastrophic events. Water Resources Research, 43, W08423.

Budd, L., S. Griggs, D. Howarth \& S. Ison (2011) A fiasco of volcanic proportions? Eyjafjallajökull and the closure of European airspace. Mobilities, 6, 31-40.

Button, K. \& J. Yuan (2013) Airfreight Transport and Economic Development: An Examination of Causality. Urban Studies, 50, 329-340. 
Carlsen, H. K., T. Gislason, B. Benediktsdottir, T. B. Kolbeinsson, A. Hauksdottir, T. Thorsteinsson \& H. Briem (2012) A survey of early health effects of the Eyjafjallajökull 2010 eruption in Iceland: a population-based study. BMJ open, 2, e000343.

Casadevall, T. J. (1994) Volcanic ash and aviation safety: proceedings of the first international symposium on volcanic ash and aviation safety. US Government Printing Office.

Casadevall, T. J., P. Delos Reyes \& D. J. Schneider (1996) The 1991 Pinatubo eruptions and their effects on aircraft operations. Fire and Mud: eruptions and lahars of Mount Pinatubo, Philippines, 625-636.

Chhetri, P., A. Hashemi, F. Basic, A. Manzoni \& G. Jayatilleke. (2012) Bushfire, heat wave and flooding - case studies from Australia. Report from the International Panel of the Weather project funded by the European Commission's 7th framework programme. Melbourne.

Clancy, J. L. (2000) Sydney's 1998 water quality crisis. American Water Works Association. Journal, 92, 55

Chang, S. E., T. L. McDaniels, J. Mikawoz \& K. Peterson (2007) Infrastructure failure interdependencies in extreme events: power outage consequences in the 1998 Ice Storm. Natural Hazards, 41, 337-358.

Chester, D. K., M. Degg, A. M. Duncan \& J. E. Guest (2001) The increasing exposure of cities to the effects of volcanic eruptions: a global survey. Global Environmental Change Part B: Environmental Hazards, 2, 89-103.

Coates, L., K. Haynes, J. O’Brien, J. McAneney \& F. D. De Oliveira (2014) Exploring 167 years of vulnerability: An examination of extreme heat events in Australia 1844-2010. Environmental Science \& Policy, 42, 33-44.

Cowie, J. H., A. T. Ogielski, B. Premore, E. A. Smith \& T. Underwood (2003) Impact of the 2003 blackouts on Internet communications. Preliminary Report, Renesys Corporation (updated March 1, 2004).

Cutter, S. L., J. T. Mitchell \& M. S. Scott (2000) Revealing the vulnerability of people and places: a case study of Georgetown County, South Carolina. Annals of the association of American Geographers, 90, 713-737.

Cutter, S. L., B. J. Boruff \& W. L. Shirley (2003) Social vulnerability to environmental hazards. Social science quarterly, 84, 242-261.

Cutter, S. L. \& C. Finch (2008) Temporal and spatial changes in social vulnerability to natural hazards. Proceedings of the National Academy of Sciences, 105, 2301-2306.

Daniell, J. E., A. M. Schaefer \& F. Wenzel (2017) Losses Associated with Secondary Effects in Earthquakes. Frontiers in Built Environment, 3.

Davis, G. (1999) The Auckland electricity supply disruption 1998: emergency management aspects. Australian Journal of Emergency Management, 13, 44-46.

Dawson, D. M. \& B. J. Brooks. (1999) The Esso Longford gas plant accident: report of the Longford Royal Commission. Government Printer, South Africa.

Department of Health (2014) The health impacts of the January 2014 heatwave in Victoria. State Government of Victoria Melbourne.

Department of Human Services (2009) January 2009 heatwave in Victoria: An assessment of health impacts. Victorian Government Department of Human Services.

Donner, W. \& H. Rodríguez (2008) Population composition, migration and inequality: The influence of demographic changes on disaster risk and vulnerability. Social forces, 87, 1089-1114.

Donovan, A. R. \& C. Oppenheimer (2011) The 2010 Eyjafjallajökull eruption and the reconstruction of geography. The Geographical Journal, 177, 4-11.

EERI. (2011) Learnings from earthquakes - the March 11, 2011, Great East Japan (Tohoku) Earthquake and Tsunami: societal dimensions. EERI Special Earthquake Report - August 2011.

Electricity Consumers Resource Council (ELCON) (2004) The Economic impacts of the August 2003 Blackout. February 2004.

Ellertsdottir, E. T. (2014) Eyjafjallajökull and the 2010 closure of European airspace: crisis management, economic impact, and tackling future risks. The Student Economic Review XXVIII, $129-137$. 
Erjongmanee, S., C. ji, J. Stokely \& N. Hightower. (2008) Large-Scale Inference of Network-Service Disruption upon Natural Disasters.

European Commission. (2011) Volcano Grimsvötn: how is the European response different to the Eyjafjallajökull eruption last year? Frequently Asked Questions. Brussels.

Farbotko, C. \& G. Waitt (2011) Residential air-conditioning and climate change: voices of the vulnerable. Health Promotion Journal of Australia, 22, 13-16.

García-Herrera, R., J. Díaz, R. M. Trigo, J. Luterbacher \& E. M. Fischer (2010) A review of the European summer heat wave of 2003. Critical Reviews in Environmental Science and Technology, 40, 267-306.

Gertisser, R. (2010) Eyjafjallajökull volcano causes widespread disruption to European air traffic. Geology Today, 26, 94-95.

Gettleman, J. (2010) With flights grounded, Kenya's produce wilts. New York Times. https://www. nytimes.com/2010/04/20/world/africa/20kenya.html. Accessed 22/05/2019.

Giovinazzi, S., T. Wilson, C. Davis, D. Bristow, M. Gallagher, A. Schofield, M. Villemure, J. Eidinger \& A. Tang (2011) Lifelines performance and management following the 22 February 2011 Christchurch earthquake, New Zealand: highlights of resilience. Bullentin of the New Zealand Society for Earthquake Engineering, 44, 402-417.

Gislason, S. R., Hassenkam, T., Nedel, S., Bovet, N., Eiriksdottir, E. S., Alfredsson, H. A., Hem, C.P., Balogh, Z.I., Dideriksen, K., Oskarsson, N. and Sigfusson, B. (2011). Characterization of Eyjafjallajökull volcanic ash particles and a protocol for rapid risk assessment. Proceedings of the National Academy of Sciences, 108(18), 7307-7312.

Guikema, S. D. (2009) Natural disaster risk analysis for critical infrastructure systems: An approach based on statistical learning theory. Reliability Engineering \& System Safety, 94, 855-860.

Hawk, F. (1999) You Would Cry Too If It Happened to You: The Legal and Insurance Implications of Major Utility Failure. Australian Mining \& Petroleum LJ, 18, 42.

Huppert, H. E. \& R. S. J. Sparks (2006) Extreme natural hazards: population growth, globalization and environmental change. Philosophical Transactions of the Royal Society of London A: Mathematical, Physical and Engineering Sciences, 364, 1875-1888.

IATA. (2010) The impact of Eyjafjallajokull's volcanic ash plume. In IATA Economic Briefing.

Jenkins, S., R. Spence, J. Fonseca, R. Solidum \& T. Wilson (2014) Volcanic risk assessment: Quantifying physical vulnerability in the built environment. Journal of Volcanology and Geothermal Research, 276, 105-120.

Jenkins, S., T. Wilson, C. Magill, V. Miller, C. Stewart, R. Blong, W. Marzocchi, M. Boulton, C. Bonadonna \& A. Costa (2015) Volcanic ash fall hazard and risk. Global Volcanic Hazards and Risk. Cambridge University Press, Cambridge, 173-222.

Justus, F.K. (2015) Coupled effects on Kenyan horticulture following the 2008/2009 post-election violence and the 2010 volcanic eruption of Eyjafjallajökull. Natural Hazards, 76(2), 1205-1218.

Kargbo, A., J. Mao and C. Y. Wang (2010) The progress and issues in the Dutch, Chinese and Kenyan floriculture industries. African Journal of Biotechnology, 9(44), 7401-7408.

King, A., D. McConnell, H. Saddler, N. Ison \& R. Dargaville (2016) What Caused South Australia's State-Wide Blackout? The Conversation.

Kinney, R., P. Crucitti, R. Albert \& V. Latora (2005) Modeling cascading failures in the North American power grid. The European Physical Journal B - Condensed Matter and Complex Systems, 46, 101-107.

Klein, R. J., R. J. Nicholls \& F. Thomalla (2003) Resilience to natural hazards: How useful is this concept? Global Environmental Change Part B: Environmental Hazards, 5, 35-45.

Klinger, C., O. Landeg \& V. Murray (2014) Power Outages, Extreme Events and Health: a Systematic Review of the Literature from 2011-2012. PLOS Currents Disasters. 2014 Jan 2. Edition 1.

Kummu, M. and O. Varis (2011) The world by latitudes: A global analysis of human population, development level and environment across the north-south axis over the past half century. Applied geography, 31(2), 495-507.

Lall, S. V. \& U. Deichmann (2010) Density and disasters: economics of urban hazard risk. The World Bank Research Observer, 27, 74-105. 
Langmann, B., A. Folch, M. Hensch \& V. Matthias (2012) Volcanic ash over Europe during the eruption of Eyjafjallajökull on Iceland, April-May 2010. Atmospheric Environment, 48, 1-8.

Lanzano, G., E. Salzano, F. Santucci de Magistris \& G. Fabbrocino (2014) Seismic vulnerability of gas and liquid buried pipelines. Journal of Loss Prevention in the Process Industries, 28, 72-78.

Leipold, B. and F. Morgante (2013) The impact of the flower industry on Kenya's sustainable development. International Public Policy Review, 7(2), 1-31.

Leyland, B. (1998) Auckland central business district power failure. Power Engineering Journal, $12,109-114$.

Lin, A., B. A. Fletcher, M. Luo, R. Chinery \& S. Hwang (2011) Health impact in New York city during the Northeastern Blackout of 2003. Public Health Reports, 126, 384-393.

Lindstrom, S., V. Nagalingam \& H. Newnham (2013) Impact of the 2009 Melbourne heatwave on a major public hospital. Internal medicine journal, 43, 1246-1250.

Lund, K. A. \& K. Benediktsson (2011) Inhabiting a risky earth: The Eyjafjallajökull eruption in 2010 and its impacts. Anthropology Today, 27, 6-9.

Magill, C., T. Wilson \& T. Okada (2013) Observations of tephra fall impacts from the 2011 Shinmoedake eruption, Japan. Earth, Planets and Space, 65, 18.

McEvoy, D., I. Ahmed \& J. Mullett (2012) The impact of the 2009 heat wave on Melbourne's critical infrastructure. Local Environment, 17, 783-796.

McInnes, J. A. \& J. E. Ibrahim (2013) Preparation of residential aged care services for extreme hot weather in Victoria, Australia. Australian Health Review, 37, 442-448.

Meehl, G. A. \& C. Tebaldi (2004) More intense, more frequent, and longer lasting heat waves in the 21 st century. Science, 305, 994-997.

Menoni, S. (2001) Chains of damages and failures in a metropolitan environment: some observations on the Kobe earthquake in 1995. Journal of Hazardous Materials, 86, 101-119.

Miller, N. L., K. Hayhoe, J. Jin \& M. Auffhammer (2008) Climate, Extreme Heat, and Electricity Demand in California. Journal of Applied Meteorology and Climatology, 47, 1834-1844.

Mukkala, K. \& H. Tervo (2013) Air Transportation and Regional Growth: Which Way Does the Causality Run? Environment and Planning A: Economy and Space, 45, 1508-1520.

Mullett, J. \& D. McEvoy (2014) With more heatwaves to come, how will our cities hold up? . The Conversation, 17 January 2014.

Murray, A. T. (2013) An overview of network vulnerability modelling approaches. GeoJournal, 78, 209-221.

Murray, A. T. \& T. Grubesic. (2007) Critical infrastructure: Reliability and vulnerability. Springer Science \& Business Media.

Nowakowska, M. (2015) Safety of Supply Chain of Kenya's Cut Flower Industry. Case of Kongoni River Farm. Logistics and Transport, 26(2), 43-48.

O'Regan, M. (2011) On the Edge of Chaos: European Aviation and Disrupted Mobilities. Mobilities, 6, 21-30.

O'Rourke, T., S. Jeon, S. Toprak, M. Cubrinovski \& J. Jung. (2012) Underground lifeline system performance during the Canterbury earthquake sequence. In Proceedings of the 15th world conference on earthquake engineering, Lisbon, Portugal, 24.

Oxford Economics (2010) The economic impacts of air travel restrictions due to volcanic ash. A report prepared for airbus.

Palecki, M. A., S. A. Changnon \& K. E. Kunkel (2001) The nature and impacts of the July 1999 heat wave in the midwestern United States: learning from the lessons of 1995. Bulletin of the American Meteorological Society, 82, 1353-1367.

Parker, C. F. (2015) Complex negative events and the diffusion of crisis: lessons from the 2010 and 2011 Icelandic volcanic ash cloud events. Geografiska Annaler: Series A, Physical Geography, 97, 97-108.

Pedersen, P. O. (2001) Freight transport under globalisation and its impact on Africa. Journal of Transport Geography, 9, 85-99. 
Petkova, E. P., H. Morita \& P. L. Kinney (2014) Health impacts of heat in a changing climate: how can emerging science inform urban adaptation planning? Current epidemiology reports, 1 , $67-74$

Porkelsson, B., Karlsdóttir, S., Gylfason, Á. G., Höskuldsson, Á., Brandsdóttir, B., Ilyinskaya, E., Guðmundsson, M.T. and Högnadóttir, P. (2012). The 2010 Eyjafjallajökull eruption, Iceland: report to ICAO-June 2012.

Przedpelski, Z. J. \& T. J. Casadevall. (1994) Impact of volcanic ash from 15 December 1989 Redoubt volcano eruption on GE CF6-80C2 turbofan engines. In Volcanic ash and aviation safety: Proc. of the First International Symposium on Volcanic Ash and Aviation Safety, 129-135.

Reeves, J., C. Foelz, P. Grace, P. Best, T. Marcussen, S. Mushtaq, R. Stone, M. Loughnan, D. McEvoy \& I. Ahmed. (2010) Impacts and adaptation response of infrastructure and communities to heatwaves: the southern Australian experience of 2009. National Climate Change Adaptation Research Facility.

Revi, A., D. E. Satterthwaite, F. Aragón-Durand, J. Corfee-Morlot, R. B. R. Kiunsi, M. Pelling, D. C. Roberts \& W. Solecki. (2014) Urban areas. In Climate Change 2014: Impacts, Adaptation, and Vulnerability. Part A: Global and Sectoral Aspects. Contribution of Working Group II to the Fifth Assessment Report of the Intergovernmental Panel on Climate Change, eds. C. B. Field, V. R. Barros, D. J. Dokken, K. J. Mach, M. D. Mastrandrea, T. E. Bilir, M. Chatterjee, K. L. Ebi, Y. O. Estrada, R. C. Genova, B. Girma, E. S. Kissel, A. N. Levy, S. MacCracken, P. R. Mastrandrea \& L.L.White, 535-612. Cambridge, United Kingdom and New York, NY, USA: Cambridge University Press.

Rinaldi, S. M., J. P. Peerenboom \& T. K. Kelly (2001) Identifying, understanding, and analyzing critical infrastructure interdependencies. IEEE Control Systems, 21, 11-25.

Rodrigue, J.-P., C. Comtois \& B. Slack. (2017) The geography of transport systems. Taylor \& Francis.

Rose, A., J. Benavides, S. E. Chang, P. Szczesniak \& D. Lim (1997) The regional economic impact of an earthquake: Direct and indirect effects of electricity lifeline disruptions. Journal of Regional Science, 37, 437-458.

Rose, A. Z. \& G. Oladosu. (2008) Regional economic impacts of natural and man-made hazards: disrupting utility lifeline services to households. In Economic impacts of Hurricane Katrina, ed. H. Richardson, Gordon, P. and Moore, J., 187-207. Cheltenham: Edward Elgar.

Salamanca, F., Georgescu, M., Mahalov, A., Moustaoui, M., \& Wang, M. (2014). Anthropogenic heating of the urban environment due to air conditioning. Journal of Geophysical Research: Atmospheres, 119(10), 5949-5965.

Scorcher (2019) Welcome to Scorcher. https://scorcher.org.au/ Accessed 10/1/2019.

Siebert, L., T. Simkin \& P. Kimberly. (2011) Volcanoes of the World. Univ of California Press.

Singh, E. A. (2019) Modelling the impact of lifeline infrastructure failure during natural hazard events. Doctoral dissertation, Macquarie University, Faculty of Science and Engineering, Department of Environmental Sciences https://hdl.handle.net/1959.14/1268491.

Small, C. \& T. Naumann (2001) The global distribution of human population and recent volcanism. Global Environmental Change Part B: Environmental Hazards, 3, 93-109.

Stevenson, J. (2012) An Icelandic eruption 100 times more powerful than Eyjafjallajökull. 2017. https://all-geo.org/volcan01010/2012/04/an-icelandic-eruption-100-times-morepowerful-than-eyjafjallajokull/. Accessed 24/06/2018.

Stevenson, J., S. Loughlin, C. Rae, T. Thordarson, A. Milodowski, J. Gilbert, S. Harangi, R. Lukács, B. Højgaard \& U. Árting (2012) Distal deposition of tephra from the Eyjafjallajökull 2010 summit eruption. Journal of Geophysical Research: Solid Earth, 117.

Swindles, G. T., I. T. Lawson, I. P. Savov, C. B. Connor \& G. Plunkett (2011) A 7000 yr perspective on volcanic ash clouds affecting northern Europe. Geology, 39, 887-890.

Sword-Daniels, V., T. Wilson, S. Sargeant, T. Rossetto, J. Twigg, D. Johnston, S. Loughlin \& P. Cole (2014) Consequences of long-term volcanic activity for essential services in Montserrat: challenges, adaptations and resilience. Geological Society, London, Memoirs, 39, 471-488. 
US-Canada Power System Outage Task Force (2004) Final report on the august 14, 2003 blackout in the United States and Canada: causes and recommendations. US Department of Energy.

Van Aalst, M. K. (2006) The impacts of climate change on the risk of natural disasters. Disasters, 30, 5-18.

Victoria State Government. (2015) How to cope and stay safe in extreme heat. ed. Department of Health \& Human Services. Melbourne.

Wadhams N (2010) Iceland volcano: Kenya's farmers losing $\$ 1.3 \mathrm{~m}$ a day in flights chaos. The Gaurdian https://www.theguardian.com/world/2010/apr/18/iceland-volcano-kenya-farmers. Accessed 22/05/2019.

Webley, P. (2015) Volcanoes and the aviation industry. Global volcanic hazards and risk, 295.

Wilson, T. M., J. Cole, C. Stewart, S. Cronin \& D. Johnston (2011) Ash storms: impacts of wind-remobilised volcanic ash on rural communities and agriculture following the 1991 Hudson eruption, southern Patagonia, Chile. Bulletin of Volcanology, 73, 223-239.

Wilson, T. M., C. Stewart, V. Sword-Daniels, G. S. Leonard, D. M. Johnston, J. W. Cole, J. Wardman, G. Wilson \& S. T. Barnard (2012) Volcanic ash impacts on critical infrastructure. Physics and Chemistry of the Earth, Parts A/B/C, 45-46, 5-23.

Open Access This chapter is licensed under the terms of the Creative Commons Attribution 4.0 International License (http://creativecommons.org/licenses/by/4.0/), which permits use, sharing, adaptation, distribution and reproduction in any medium or format, as long as you give appropriate credit to the original author(s) and the source, provide a link to the Creative Commons license and indicate if changes were made.

The images or other third party material in this chapter are included in the chapter's Creative Commons license, unless indicated otherwise in a credit line to the material. If material is not included in the chapter's Creative Commons license and your intended use is not permitted by statutory regulation or exceeds the permitted use, you will need to obtain permission directly from the copyright holder.

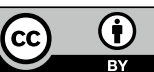

